\title{
Maxillary complete denture and mandibular All-on-4 implant restoration considering maintenance: a case report
}

\author{
So-Yeun Kim,3 Eun-Young Kwon', Kyoung-Hwa Jung,' Hye-Mi Jeon', Eun-Sook Kang ${ }^{1}$, Mi-Jung Yun ${ }^{3 *}$ \\ 'Dental Clinic Center, Pusan National University Hosptial, Busan, Republic of Korea \\ ${ }^{2}$ Department of Prosthodontics, In-Je University Haeundae Paik Hospital, Busan, Republic of Korea \\ ${ }^{3}$ Department of Prosthodontics, School of Dentistry, Pusan National University, Yangsan, Republic of Korea
}

In the case of edentulous patients, the total amount of occlusal force is dispersed by the keratinized gingiva during mastication, in result, causing lower masticatory and chewing efficiency. In particular, the mandibular area has more side effects such as pain than the maxilla has. It gets worse when the patient has more absorption of alveolar bone, but the implant treatment is often interrupted due to the existence of the inferior alveolar nerve. In this case, a patient treated with the all-on-4 method by placing the implant in the anterior part of mandible and with the conventional complete denture for the maxilla has maintained without complications and was satisfied with the restoration both functionally and esthetically. (J Dent Rehabil Appl Sci 2019;35(1):37-45)

Key words: all-on-4; mandibular edentulous patient; tilted implant

\begin{abstract}
서론
치조골과 치주인대의 지지를 받는 자연 치열과 달리 완 전 무치악에서는 무치악 치조제의 각화 점막을 통해 모 든 교합력을 받는다. 따라서 저작력이 자연치의 $1 / 5$ $1 / 6$ 정도로 떨어지고 점막의 자극으로 인해 불편하며 전 체적으로 저작 능률 저하를 보이게 된다. ${ }^{1}$ 하악 무치악 환자의 총의치 치료의 경우에는 상악의 경우보다 지지 면적이 작고 변연 봉쇄를 얻기 어렵기 때문에 유지력과 안정성을 얻기가 더 어렵다. ${ }^{2}$ 하악 치조골의 심한 위축은 환자로 하여금 더 이상 의치 장착이 힘들 정도의 불편한 상태를 만든다. 이를 해결하기 위해서 임플란트 치료를 고려했을 때, 교합력이 더 크게 발생하는 구치부에는 뼈 흡수와 하치조 신경관의 존재 때문에 치조골 높이가 불 충분하여 임플란트 식립이 불가능한 경우가 많다. ${ }^{3}$
\end{abstract}

*Correspondence to: Mi-Jung Yun

Professor, Department of Prosthodontics, School of Dentistry, Pusan National University, 20, Geumo-ro, Mulgeum-eup, Yangsan, 50612, Republic of Korea Tel: +82-55-360-5134, Fax: +82-55-360-5130, E-mail: p-venus79@hanmail.net Received: December 18, 2018/Last Revision: January 7, 2019/Accepted: January 21, 2019
하악 구치부의 골퇴축이 발생한 환자에서 all-on-4 개 념은 유용하게 사용될 수 있다. 이는 임플란트 치료가 용 이하고 성공률이 높은 상하악의 전방부에 4 개의 임플란 트 만을 식립하여 충분한 성공률을 보인다는 개념이다. ${ }^{4}$ All-on-4 방식은 후방 임플란트 고정체를 이공 전방에서 경사시킴으로써 캔틸레버 길이의 감소, 임플란트 사이의 전후방 거리(anterior posterior spread, AP spread)증가, 임플란트 고정체 길이 증가, 골이식 수술 필요성 감소 등 의 장점이 있다. ${ }^{5}$ 이는 역사가 오래되어 치료의 유효성이 보고되어 왔으며 환자 역시 적은 비용으로 임플란트 고 정성 보철치료를 받을 수 있다는 장점을 가지고 있다. ${ }^{6}$

대합되는 반대악의 상태는 중요한 고려 요소 중 하나 이다. 본 증례에서 하악 캔틸레버 고정성 보철물의 대합 치로는 상악 총의치로서 구개 전체 지지 면적이 하악 고 정성 보철물로부터의 부하를 나누는 동시에 반대로 상악

Copyright C 2019 The Korean Academy of Stomatognathic Function and Occlusion. (c) It is identical to Creative Commons Non-Commercial License. 
이 하악 캔틸레버에 전달하는 부하도 과도하지 않다. 이 때 최적의 의치 적합과 의치의 균등한 응력 분포, 양측성 균형 교합 등을 통해 장기적으로 상악 무치악 치조골 소 실을 예방할 수 있다. ${ }^{7,8}$

본 증례에서는 상하악 무치악 환자에서 상악은 가철 성 총의치, 하악은 4 개의 임플란트를 이용한고정성 보철 물로 치료하였으며 환자의 요구에 따라 최소한의 비용을 목표로 치료하였다. 이후 2 년간의 관찰 기간 동안 심미적, 기능적으로 안정적 예후를 보여 이를 보고하고자 한다.

\section{증례보고}

본 증례의 환자는 59세의 여성으로, 저작 불편감과 동 통을 주소로 내원하였다. 초진 시 상, 하악 잔존치는 모 두 무면허 불법 시술자에게서 제작한 고정성 보철물로 수복된 상태였으며, 불량한 구강 위생 상태와 만성 치주 염으로 모든 잔존치의 발거가 필요한 상태였다(Fig. 1).

환자는 최소한의 비용으로 치료받기를 원하였으므로 제한된 비용 범위 내에서 최대의 효율을 얻기 위한 치료 계획을 수립하였다. 잔존 치조제의 흡수가 진행되어 총 의치 사용 시 안정성 확보가 어려울 것으로 예상되는 하 악골에만 임플란트를 식립하여 상악은 총의치, 하악은 임플란트 캔틸레버 보철물을 제작하기로 계획하였다.

전악 발치 후 상, 하악 임시 의치를 제작하여 환자가 심 미적, 기능적인 요소를 만족하면서 안정적으로 사용하는 것을 확인하고, 3 개월 후 임플란트 식립을 위한 진단용 방사선 사진을 촬영하였다. 파노라마 방사선 사진에서 하악 후방 구치부는 치조골 흡수가 심하여 임플란트를 식립하기 어려울 것으로 예상되었으므로 하악 좌우측 제

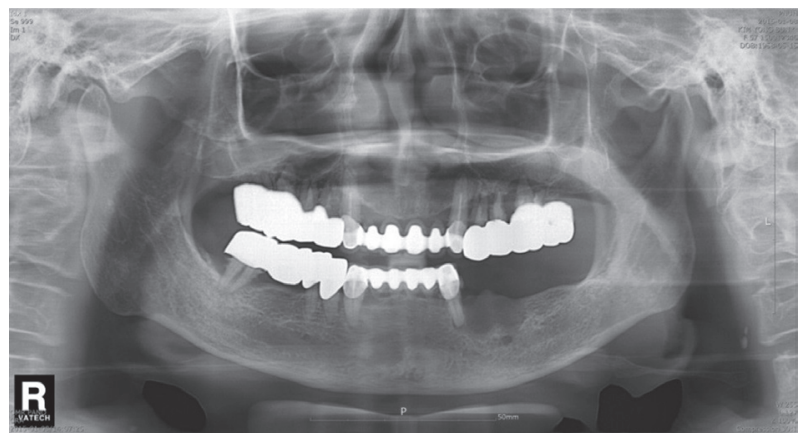

Fig. 1. Pre-operate panoramic radiograph showing alveolar bone loss due to periodontal problem.
2소구치, 견치 위치에만 임플란트를 식립하기로 계획하 였다. 그러나 구내 검사 및 진단 모형 상에서 적합하다고 예상되었던 하악 양측 제 2 소구치 부위는 하방에 하악관 이 위치하여 임플란트를 식립하기에는 수직적인 잔존골 의 양이 부족하였다. 따라서 임플란트 식립 위치를 이공 전방으로 이동하여 식립하되 약 30 도 각도만큼 후방 경 사시키고 플랫폼은 처음 계획했던 제 2 소구치 부위로 위 치할 수 있도록 All-on-4 방식을 적용하기로 하였다.

진단용 스텐트를 수정하여 제작한 수술용 스텐트를 사 용하여 하악 전치부와 이공 전방부에 직경 $4.0 \mathrm{~mm}$, 높 이 $11.5 \mathrm{~mm}$ 의 4 개의 외부 육각 연결형 임플란트(US III, Osstem Co., Seoul, Korea)를 식립하였다. 초기 고정은 모두 우수하여 치유 지대주를 바로 연결하였으며 수술 2 주 후 봉합사를 제거하였다. 사용 중이었던 임시 의치 는 수술 후 치유 지대주와 맞닿는 부분의 내면을 삭제하 여 공간을 형성한 후 연성 이장재(Soft-liner, GC, Tokyo, Japan)로 이장하여 치유 기간 동안 사용하였다(Fig. 2).

임플란트 식립 3개월 후, 알지네이트 인상을 채득하여 진단 모형을 제작하고 구멍(hole)이 있는 개인 트레이를 제작하였다. 하악은 모델링 컴파운드(Modeling Compound, Kerr Corp, Orange, USA)로 개인 트레이에 변연 형성을 시행한 뒤 폴리비닐실록산 인상재(Aquasil Ultra XLV, Densply International Inc., Milford, USA)를 이용 하여 고정체 수준에서 임플란트 인상을 채득하였고, 상 악은 통법대로 총의치 인상을 채득하였다(Fig. 3). 구강 내에서 악간 관계 기록을 채득할 때 기록상의 움직임을

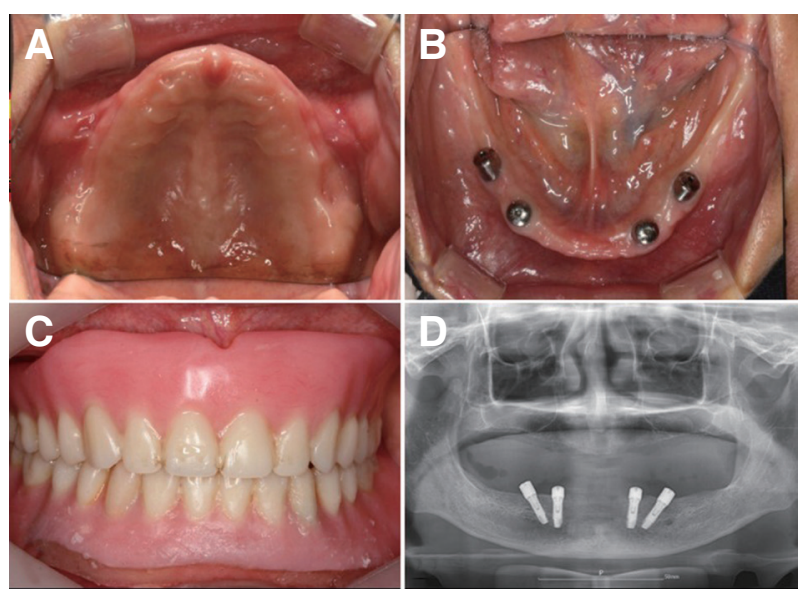

Fig. 2. (A, B) intraoral view after extraction of tooth and implant surgery, (C) Provisional denture, (D) Panoramic view after surgery. 

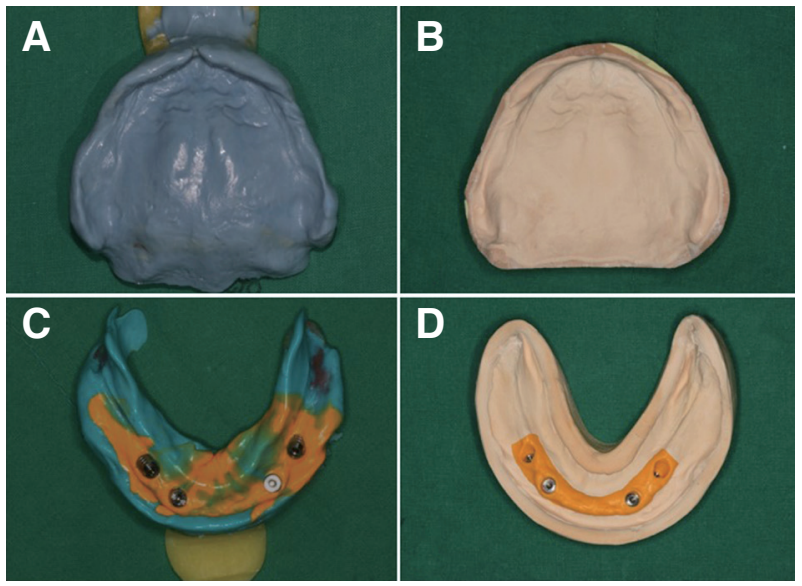

Fig. 3. Impression taking. (A, B) Definitive impression taking and master cast fabrication for conventional maxillary complete denture, (C, D) Fixture level impression taking and mandibular cast fabrication.
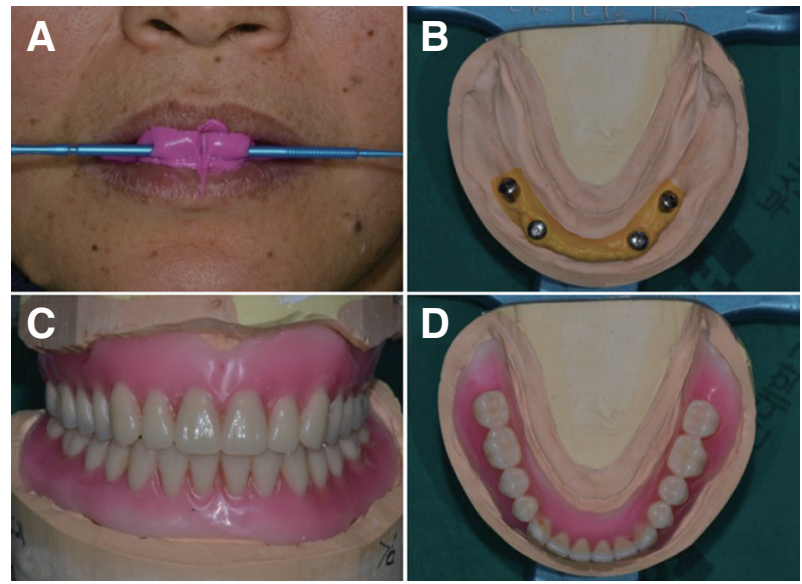

Fig. 4. (A) Recording of maxillomandibular jaw relationship using wax rim, (B) Mandibular model with the same size of healing abutments in the mouth, (C) Wax dentures of artificial tooth arrangement, (D) Mandibular wax denture placed on the model with the healing abutments.
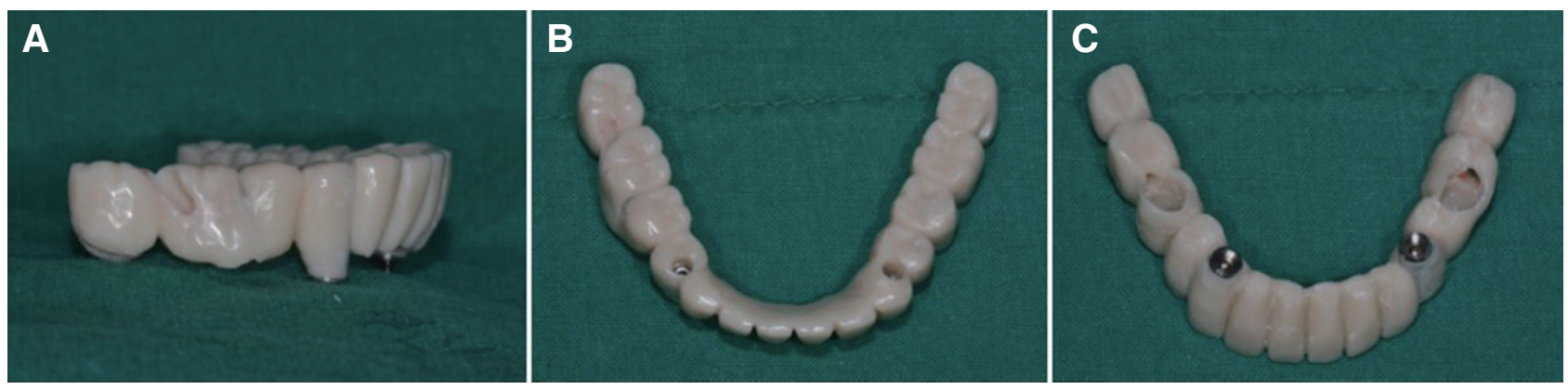

Fig. 5. Mandibular full-contour wax-up entirely connected anterior abutments and designed to cemented with the posterior abutments.

최소화하기 위해 주모형의 임플란트 유사체(lab analog) 상에 구강 내와 같은 크기의 치유 지대주를 체결한 후 기 록상과 교합제를 제작하고, 기존 의치의 수직 고경 및 교 합 관계를 참고하여 악간 관계 채득을 시행하였다. 이를 반조절성 교합기에 부착한 후 교합제에 표시한 해부학적 위치 기록을 참고하여 상악 전치부 치아부터 심미적으로 배열하고 나머지 치아를 배열하였다(Fig. 4). 완성된 납의 치를 환자의 구강 내에 시적하여 심미성을 평가하고 교 합 및 수직 고경을 확인하였다.

상, 하악 인공치를 배열하여 치아의 위치를 결정하 고 나서, 정해진 상악 치아의 위치를 기준으로 하악 고 정성 임플란트 보철물을 디자인하였다. 최종 보철물은 나사 접근이 가능하게 하고 탈부착(retrievability)을 쉽 게 하기 위해서, 전방에 식립된 2개의 임플란트 지대주
는 상부 보철과 일체형으로 제작하였고 삽입 방향이 다 른 2 개의 후방 임플란트 지대주는 상부 보철물과 임시 시멘트 (Cavex Temporary Cement, Cavex Holland BV, Haarlem, Netherlands)로 연결하되 최종 보철물에 hole 을 형성하여 구강 내에서 드라이버가 나사까지 접근 가 능하도록 계획하였다. 후방 지대주(CCM abutment, NCR200, Osstem Co.)는 육각 형태를 가지는 지대주 (hex type abutment)를 사용하여 교합평면에 수직한 방 향으로 따로 납형 형성하고, 전방 지대주(CCM abutment, NCR100, Osstem Co.)는 육각을 가지지 않는 형 태 지대주 (non-hex type abutment)를 선택하여 상부 납 형에 연결 디자인하였다(Fig. 5). 최종 납형을 구강 내에 서 시적하여 적합을 확인하고, 상부 보철 납형은 되깍임 (cut-back)을 시행한 후 전방 지대주와 연결된 상부 보철 
금속 구조, 후방 지대주를 주조하였다(Fig. 6). 주조된 후 방 지대주와 전방 금속 프레임을 구내 시적하여 후방 지 대주와 코핑 사이, 전방 지대주와 임플란트 고정체 사이 의 계면 적합을 확인하고 수정 후 최종 바이트를 채득하 였다(Fig. 7). 이후 하악 교합면까지 도재 축성 및 소성하
고 상악 의치는 온성하였다. 하악 보철물은 개구 시 교합 면이 노출되므로 심미성을 고려하여 교합면을 도재로, 상악 총의치는 레진치가 대합치에 의해 교모되어 장기적 으로 수직 고경 감소 등의 변화가 일어나는 것을 줄이기 위해 구치부에 금속 교합면을 부여하였다(Fig. 8).
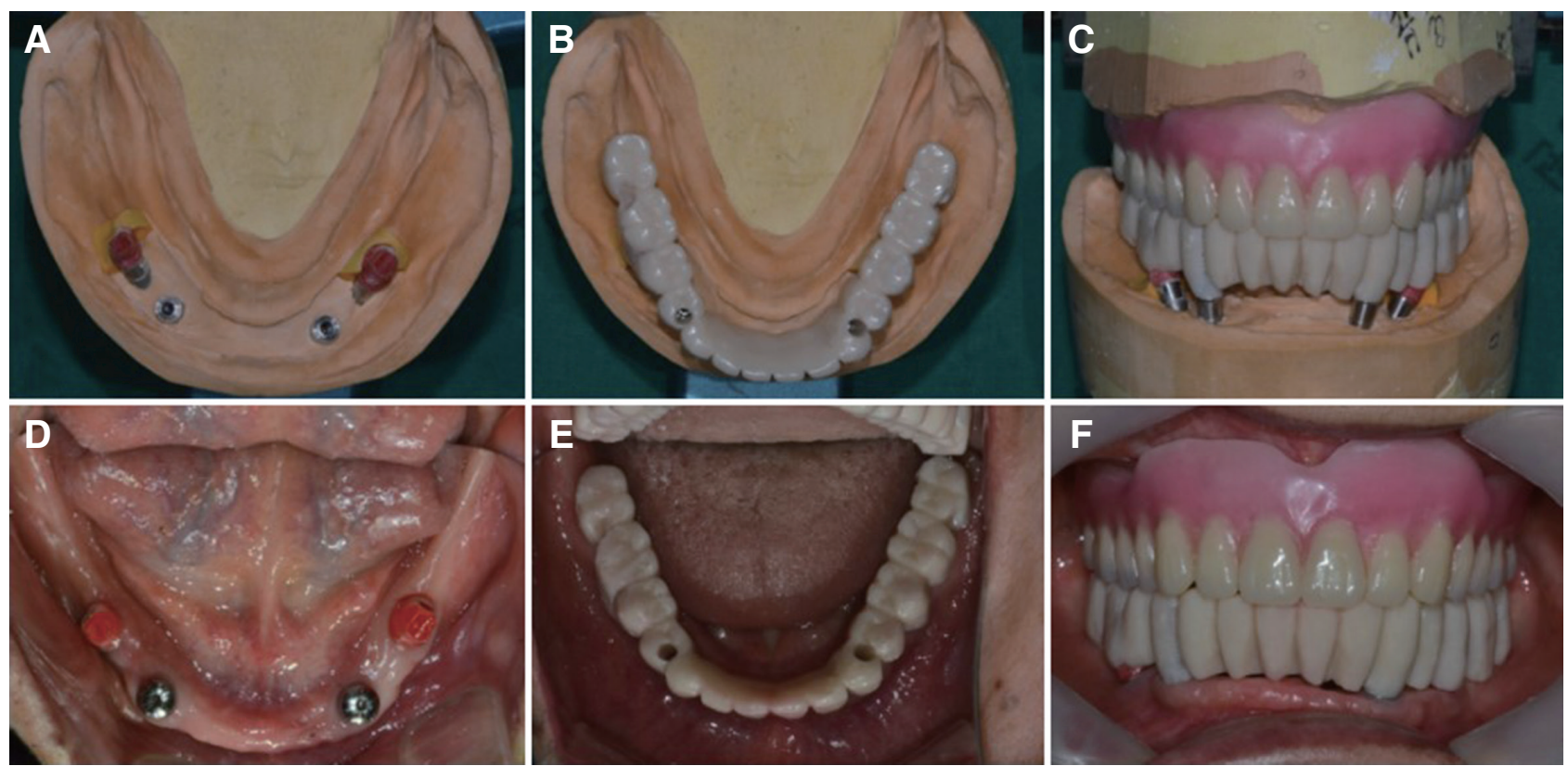

Fig. 6. (A) Screw connected posterior abutment wax-ups, (B) Mandibular wax-up model above the posterior abutment wax-ups, (C) Frontal view of maxillomandibular wax model, (D, E, F) Intraoral views of wax model try in.
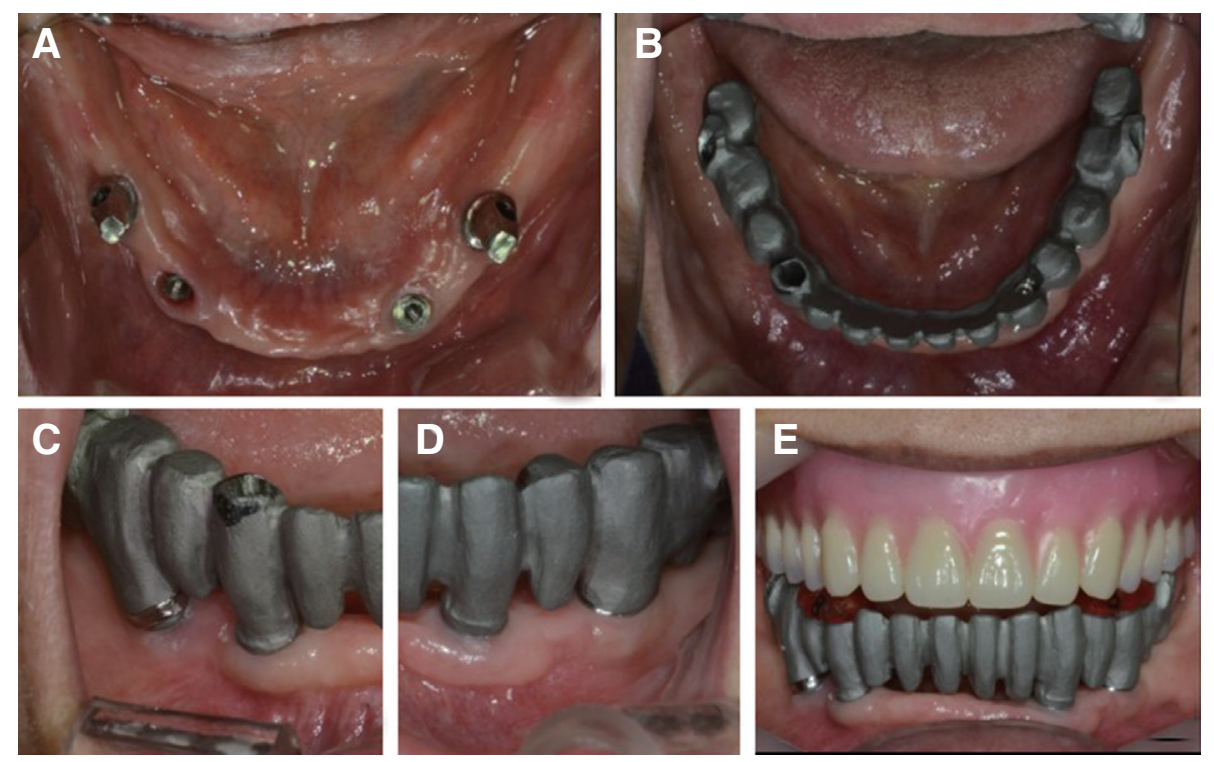

Fig. 7. (A) Connection of posterior CCM abutments in the mouth, (B) Try-in of cut-back framework which remained occlusal contact points on functional cusps of bilateral mandibular first molars, (C, D) Making on the site of lack of cutback, (E) Definitive inter-arch jaw relation taking. 
최종 하악 임플란트 보철물을 환자에게 시적하여 수 동적 적합성(passive fit) 및 변연(margin) 정확도를 확인 한 후 상악 의치의 적합도와 안정성, 하악과의 교합 관계 를 확인하고 조절하였다. 최종 장착 시, 먼저 후방 임플란 트 지대주를 $30 \mathrm{Ncm}$ 로 연결하고 테플론과 caviton으로
접근 통로(access hole)를 막은 후 상부 보철물의 내면에 임시 시멘트를 적용하여 구내 장착하고 전방 임플란트 의 나사를 조였다. 하악 임플란트 상부 보철물 상에서 접 근통로를 레진으로 막은 후 최종 상, 하악 보철물 교합을 재확인하였다(Fig. 9).

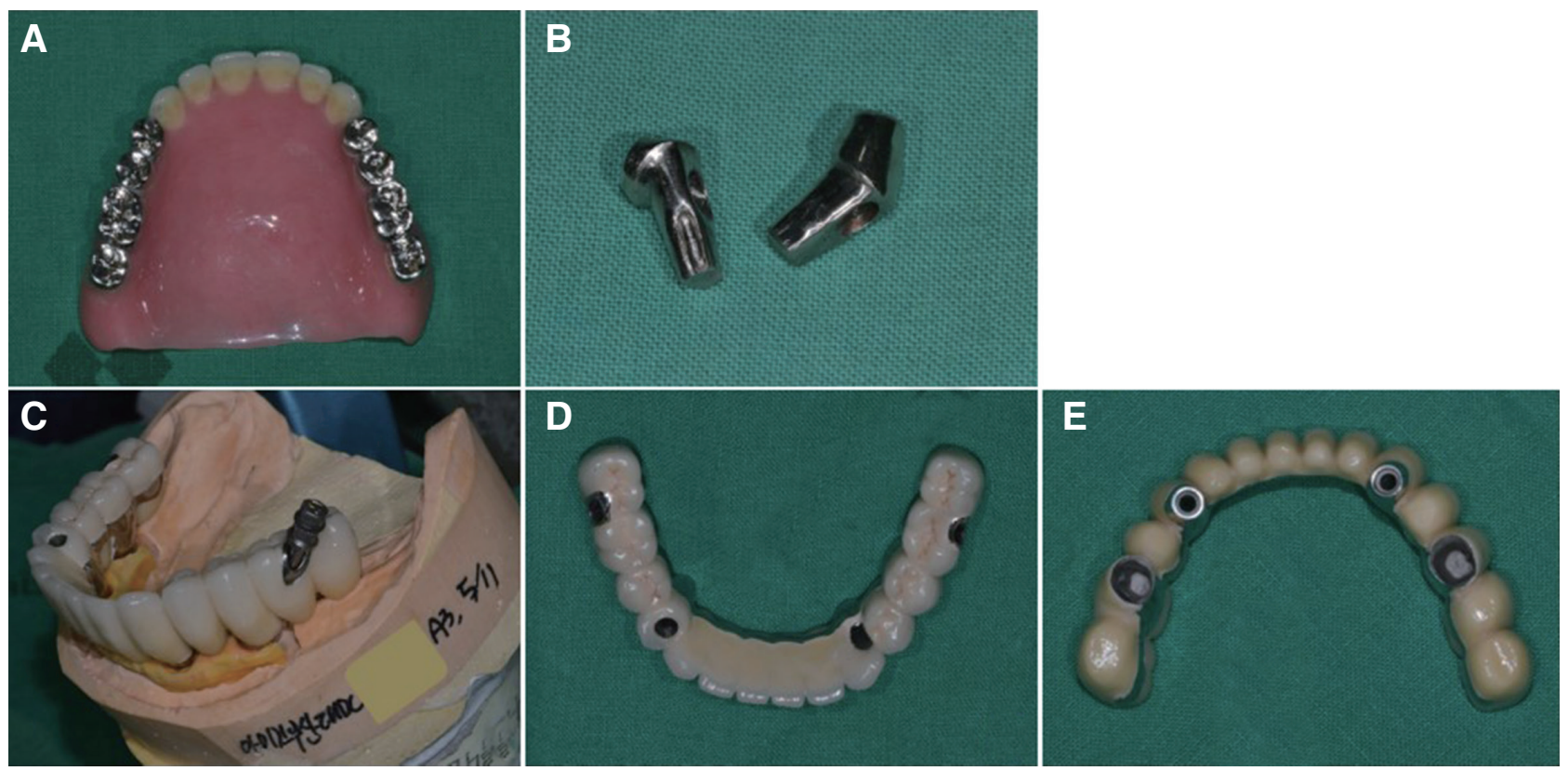

Fig. 8. Definitive prosthesis. (A) Metal occlusal surfaces on maxillary molars, (B) Posterior casted abutments, (C) Approach of implant driver on the final prosthesis, (D) Occlusal view of mandibular prosthesis, (E) Lingual view of mandibular prosthesis.
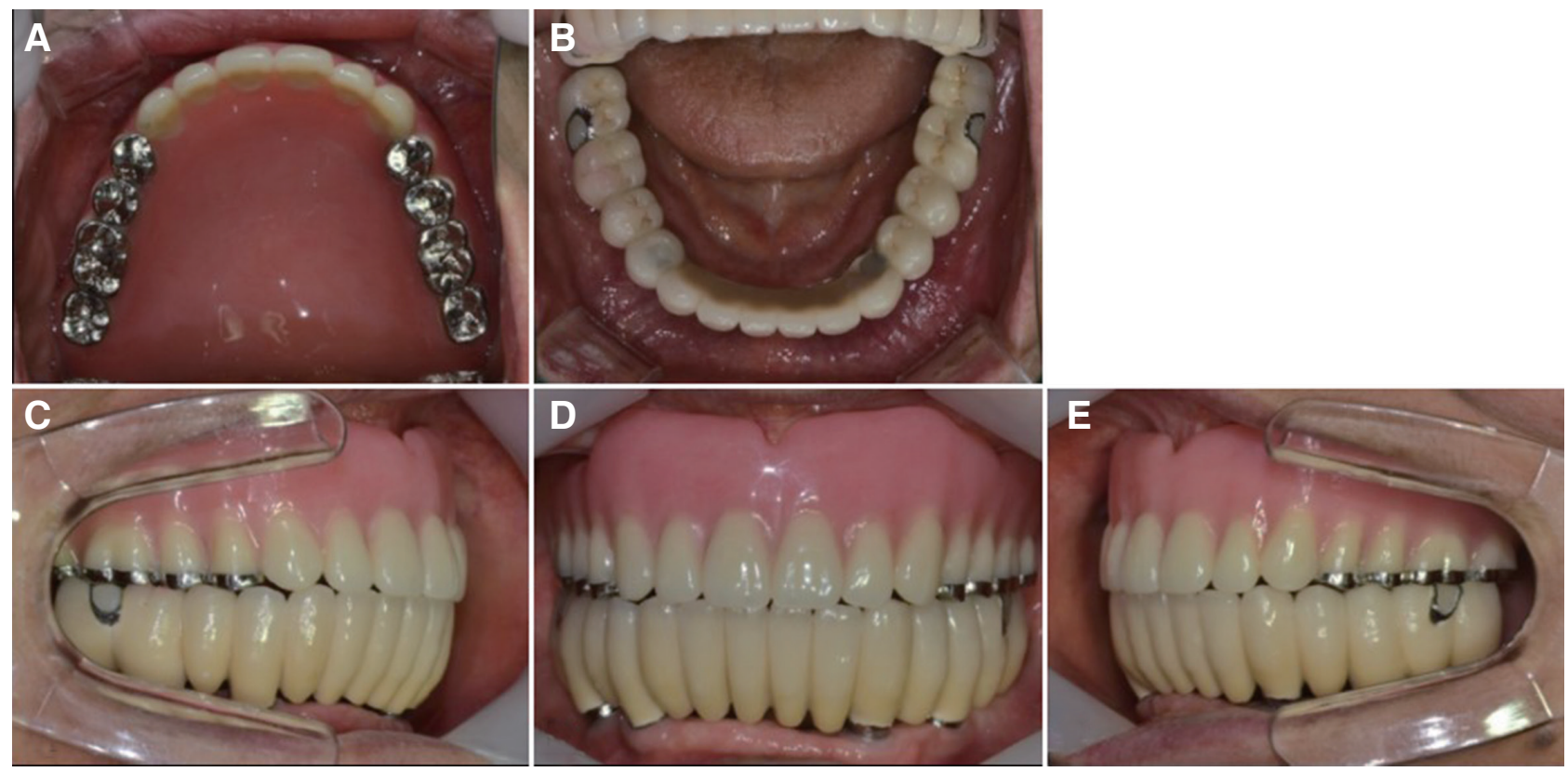

Fig. 9. Try-in view of Definitive prosthesis. 


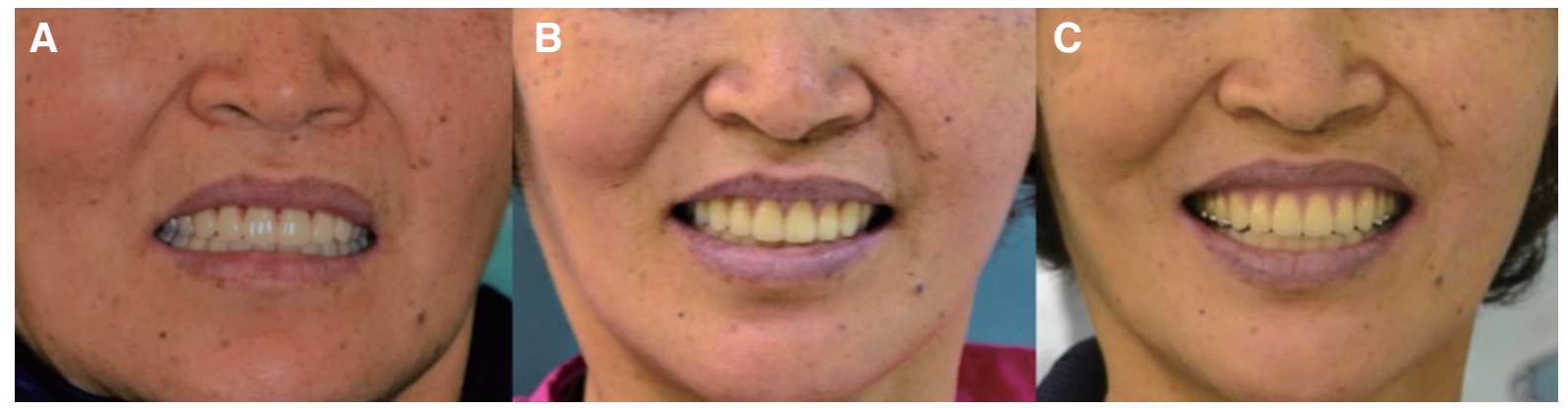

Fig. 10. (A) First day of provisional denture, (B) Day of definite restoration delivery, (C) One year after delivery, Change and improvement of smile line.

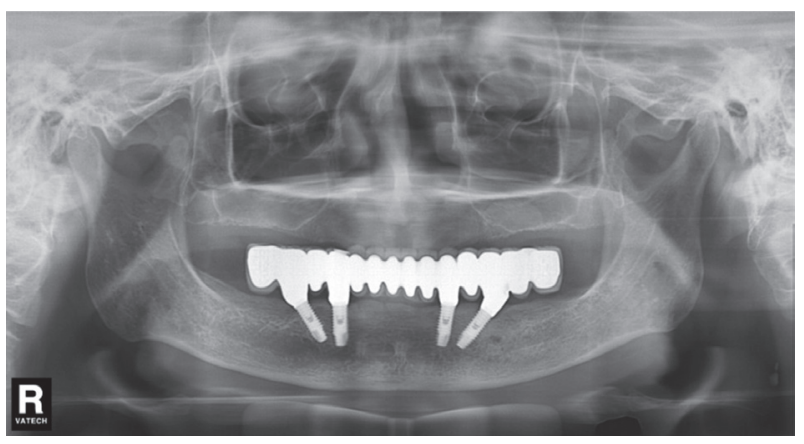

Fig. 11. Panoramic view after 3 years. No significant changes were observed.

이후 정기적 관찰 및 유지 관리 시 간단한 내면 조정과 교합 조정을 시행하였고 특별한 문제는 관찰되지 않았 다. 최종 보철 장착 약 3 년 후 촬영한 방사선 사진에서 임 플란트 주변 골흡수 양상은 관찰되지 않았고 구내 검사 에서도 염증 소견 없이 잘 유지되고 있었다. 환자 스스로 도 구강 위생을 잘 관리하고 있었으며 보철 장착 후 얼굴 근육 사용 및 자신감 증가로 인해 스마일 라인이 크게 개 선되어 매우 만족하였다(Fig. 10,11).

\section{고찰}

이 환자의 경우 상악은 총의치, 하악은 4개의 임플란트 를 이용한 고정성 임플란트 보철을 완성하였다. 하악의 경우 4개의 임플란트 고정체로 12 개의 상부 치아 형태를 유지, 지지하여야 하며 이때 하중 분포가 생역학적으로 조화롭지 못할 시 임플란트 주변 조직과 보철물의 파괴, 임플란트 자체의 파절 또는 임플란트와 보철물 연결부의 손상 등 여러 가지 문제가 발생할 수 있다. ${ }^{9}$ All-on-4의 경
우 후방 캔틸레버의 길이가 짧고 전후방 임플란트 거리 는 길게 되도록 하여 하중 분산면에서 유리하다. 상악의 경우 편악 총의치이므로 힘의 균형이 무너져 있을 경우 복합 증후군(combination syndrome) 증상과 유사한 골 흡수 양태를 보일 위험이 있다. 이를 방지하기 위해 양측 성 균형교합과 단일 평면의 교합면 설정, 전치부의 교합 접촉을 없도록 하는 방법으로 하악 임플란트에 대한 상 악 전방부 골흡수를 예방하도록 권고된다. ${ }^{10}$

임플란트 보철물은 연결방식에 따라서 외부 연결방 식(external connection type)과 내부 연결방식(internal connection type)으로, 유지 방법에 따라 접착 유지형 (cemented-retained)과 나사 유지형(screw-retained)으로 나눌 수 있다. 외부 연결방식은 지대주와 임플란트 고정 체 사이 연결부분을 육안으로 확인하기 쉬우며, 다양한 보철적 옵션이 존재하여 임플란트 식립 각도가 다양한 다수 임플란트 보철 수복 시에 유리하다. 나사 유지형은 나사 조임을 통한 보철물 철거 및 재장착이 자유로운 반 면 접착 유지형은 시멘트 공간이 상부 보철물의 수동적 인 적합이 가능하도록 하나 보철물 착탈의 어려움이 있 다. ${ }^{11,12}$ 본 환자는 보철 디자인의 유연성을 위해 외부 연결 방식의 임플란트를 식립하였다. 보철물의 유지관리를 고 려하여 전방의 직립된 임플란트 고정체에는 나사 유지형 으로, 후방의 경사된 임플란트 고정체에는 접착 유지형 으로 하되 나사 구멍은 구강 내에서 접근 가능하고, 시멘 트는 임시 시멘트로 약하게 접착시켜 놓아 탈락력이 가 해졌을 때 쉽게 제거될 수 있도록 계획하였다. 후방 지대 주는 치은 상부로 변연을 갖는 동시에 상부 보철물 하부 구조를 유지하고 지지하는 면적을 더 넓게 확보할 수 있 도록 납형 제작과 주조 과정으로 제작하였다. 밀링으로 제작하는 맞춤 지대주는 제작 시 사용되는 환봉 자체의 
두께가 한계가 있기 때문에 경사진 지대주의 제작 시 특히 나사 구멍 부분으로의 연장이 부족할 수 있다. 전방 임플 란트 지대주 부분은 나사 유지형으로 상부 보철물과 하나 로 연결되어 전방 임플란트의 나사만 풀어주면 하악 보철 물 전체가 한 몸체로 쉽게 착탈되도록 디자인하였다.

의치용 레진치는 구치부 교합면의 급속한 마모 및 낮 은 경도가 문제로 지적된다. 낮은 경도로 인한 심한 인공 치의 마모는 교합고경과 교합관계에 심각한 영향을 끼친 다. ${ }^{13}$ 특히 레진치가 도재와 대합되면 마모가 더욱 가속 화되므로 본 증례에서는 상악 레진치 교합면 위에 금속 교합면을 부여하였다. 상악이 가철성 장치이고 환자의 나이와 성별을 고려할 때 도재의 파절은 우려가 적을 것 으로 생각하였고 경과 기간 동안 도재 파절이나 금속 교 합면의 탈락은 없었다.

치주 질환으로 전체 치아를 발치하고 처음으로 완전 무치악이 된 환자에서 경제성을 고려하되 총의치 사용으 로 인한 불편감을 최소로 하기 위한 목적으로 계획한 보 철 디자인에서 All-on-4를 사용하였다. 장기간의 보철 안 정과 유지를 위해 금속 교합면 부여, 임플란트 나사 구멍 형성 등의 부가적인 처치와 함께 정기적인 교합 체크를 하고 있다. 보철 수복 후 안모의 회복과 저작 능률의 회 복으로 만족감을 나타냈으며 3년 간의 관찰 결과 합병증 이나 변화 없이 유지되고 있다.

\section{결론}

완전 무치악 환자에서 상악은 총의치 보철, 하악은 Allon-4 방식으로 고정성 임플란트 보철을 완성한 환자에서 저작능률에의 만족감, 장기적 보철물의 안정성, 개선된 안모와 표정을 관찰하여 술자와 환자 모두 만족한 결과 를 얻을 수 있었다.

\section{Acknowledgements}

본 연구는 2018년도 부산대학교병원 임상연구비 지원 으로 이루어졌음.

\section{ORCID}

So-Yeun Kim https://orcid.org/0000-0001-6714-8315

Eun-Young Kwon https://orcid.org/0000-0001-95550360
Kyoung-Hwa Jung https://orcid.org/0000-0002-83050016

Hye-Mi Jeon https://orcid.org/0000-0003-0007-5662 Eun-Sook Kang https://orcid.org/0000-0002-44954135

Mi-Jung Yun https://orcid.org/0000-0003-3093-8493

\section{References}

1. Rissin L, House JE, Manly RS, Kapur KK. Clinical comparison of masticatory performance and electromyographic activity of patients with complete dentures, overdentures and natural teeth. J Prosthet Dent 1978;39:508-11.

2. Wismeijer D, Van Waas MA, Vermeeren JI, Mulder J, Kalk W. Patient satisfaction with implant-supported mandibular overdentures. A comparison of three treatment strategies with ITI-dental implants. Int J Oral Maxillofac Surg 1997;26:263-7.

3. Kim YJ, Jeong SM, Kim KH, Fang JW, Kim DH, Choi BH. Application of digital implant system on implant treatment with "all-on-4" concept. J Korean Acad Prosthodont 2018;56:88-94.

4. Brånemark PI, Svensson B, van Steenberghe D. Ten-year survival rates of fixed prostheses on four or six implants admodum Brånemark in full edentulism. Clin Oral Implants Res 1995;6:227-31.

5. Kim KS, Kim YL, Bae JM, Cho HW. Biomechanical comparison of axial and tilted implants for mandibular full-arch fixed prostheses. Int J Oral Maxillofac Implants 2011;26:976-84.

6. Brånemark PI, Svensson B, van Steenberghe D. Ten-year survival rates of fixed prostheses on four or six implants admodum Brånemark in full edentulism. Clin Oral Implants Res 1995;6:227-31.

7. Tallgren A. The continuing reduction of the residual alveolar ridges in complete denture wearers: a mixed longitudinal study covering 25 years. J Prosthet Dent 1972;27:120-32.

8. Lang BR, Razzoog ME. Lingualized intergration: tooth molds and an occlusal scheme for edentulous implant patients. Implant Dent 1992;1:204-11.

9. Adell R, Lekholm U, Rockler B, Brånemark PI. A 15-year study of osseointegrated implants in the 
treatment of the edentulous jaw. Int J Oral Surg 1981;10:387-416.

10. Närhi TO, Geertman ME, Hevinga M, Abdo H, Kalk W. Changes in the edentulous maxilla in persons wearing implant-retained mandibular overdentures. J Prosthet Dent 2000;84:43-9.

11. Chung $\mathrm{CH}$, Son MK. The classification and comparison of implant prosthesis according to types of retention. Part I: screw retained prosthesis vs cement retained prosthesis. J Korean Acad Oral Maxillofac Implantology 2010;14:138-51.

12. Misch CE. Dental implant prosthetics. 1st ed. St. Louis; Mosby; 2004. p. 414-6.

13. Schuyler $\mathrm{CH}$. Full denture service as influenced by tooth forms and materials. J Prosthet Dent 1951;1:33-7. 


\section{유지 관리를 고려한 상악 총의치와 하악 All-on-4 임플란트 보철 수복 증례}

\section{김소연 ${ }^{13}$, 권은영 ${ }^{1}$ 정경화 ${ }^{1}$, 전혜미 ${ }^{1}$, 강은숙 ${ }^{2}$, 윤미정 ${ }^{3 *}$}

${ }^{1}$ 부산대학교병원 치과진료센터

${ }^{2}$ 인제대학교 해운대백병원 치과보철과

${ }^{3}$ 부산대학교 치의학전문대학원 치과보철학교실

무치악 환자의 보철치료에서 총의치를 이용한 보철 치료 시 각화 점막을 통해 교합력을 분담하므로 저작력과 저작 능률 이 떨어지고 특히 지지 점막 면적이 작은 하악의 경우 상악에 비해 통증 발생 등의 부작용이 더 많다. 치조골 흡수가 많은 환자일수록 이는 더 심화되나 하악 구치부 측의 하치조신경관의 존재 때문에 임플란트를 동반한 적극적 치료가 어려운 경우가 많다. 이에 본 증례에서는 상악에는 전통적인 총의치를 제작하고 하악은 치조골 높이가 충분한 전방부에만 임플 란트를 식립하여 all-on-4 방법으로 치료한 환자에서 좋은 경과를 보여 보고하고자 한다.

(구강회복응용과학지 2019;35(1):37-45)

주요어: all-on-4; 하악 무치악 환자; 경사형 임플란트 